\title{
COMPOSTING IN BRAZIL
}

\author{
Adriana De Schueler \\ Claudio Fernando Mahler \\ COPPE, GETRES, Waste Technology Group \\ Federal University of Rio de Janeiro RJ, Brazil
}

\begin{abstract}
In order to reduce the volume of waste to be disposed of in the landfills, and consequently increase their lifetime, solutions such as incineration, pre treatment of the waste and recycling are recommended. Composting is a method of recycling by using the organic waste nutrients, which can be utilised for agricultural fertilisation and improvement of soil structure by increasing its capacity to resist erosion. Many composting factories were built in Brazil, but few of them are still working adequately. Selection of a method depends on factors like waste characteristics, environmental, economic and social conditions of the place where it will be constructed and the organisation of the state administration. This work presents the actual state of utilisation of composting technique in Brazil, as well as some analysis of compost produced at some factories. It presents also an analysis for the reasons why after several experiences, the composting process are not implemented in Brazil in a way that it could be considered an advantageous procedure for less industrialised countries.
\end{abstract}

\section{INTRODUCTION}

A large portion of Brazilian's urban solid waste consists of organic matter. Using a technique known as composting this organic material can be transformed into soil fertiliser. Thus, composting can be viewed as a form of recycling of the organic matter. Therefore, in addition to decreasing the volume of waste and changing its final destination, avoiding unnecessary occupation of the urban waste landfills, this process can give, as a final product, a compost that could be used as an agricultural organic fertiliser. It could also improve the physical structure of the soil, increasing its capacity for erosion resistance.

In general, compost produced from urban solid waste is not well received by its consumers. Its value is low because it may present environmental contaminants, such as heavy metals, toxic elements and pathogenic organisms and low presence of important nutrients. Brazil's urban waste landfills present a high content of organic matter (Mahler, 2002) (e.g. see Table 1). 
KALMAR ECO-TECH'03

Bioremediation and Leachate Treatment

KALMAR, SWEDEN, November 25-27, 2003

Lua (1999) presented in a report called " 50 Millions put down on the waste" the drama of the Brazilian administration problems. She studied 15 cases of composting systems bought in Rio de Janeiro and observed that thirteen of them are not working anymore and just two are working under not good conditions.

Table 1. Content of organic matter in urban waste (percentile weight) (Mahler, 2002)

\begin{tabular}{llll}
\hline & \multicolumn{3}{c}{ Cities } \\
World Cities & $\%$ weight & Brazil Cities & $\%$ weight \\
\hline Peking & $45 \%$ & Salvador & $70 \%$ \\
Geneva & $28 \%$ & Manaus & $51 \%$ \\
New York & $20 \%$ & Recife & $60 \%$ \\
Nairobi & $74 \%$ & São Paulo & $52 \%$ \\
Cochabanba & $71 \%$ & Laranjal do Jari & $61 \%$ \\
Istanbul & $61 \%$ & Quatis & $59 \%$ \\
Athens & $59 \%$ & Paracambi & $63 \%$ \\
Hong-Kong & $15 \%$ & & \\
Bangkok & $44 \%$ & & \\
\hline
\end{tabular}

\section{COMPOSTING}

Composting can be used for decomposition and humification of large volumes of organic material outside of soil, either in factories used specifically for this process or where factors that limit the process can be well controlled. Basically, there are two stages to the transformation of organic waste into humus:

Digestion. The first phase of degradation. It ends when the material becomes biostabilised. In this phase, the decomposition is still not complete although the compost may be used without damage to the plants. It is an imperfect fertilizer because it contains minimal colloid. However, the process of increasing quantity of hummus can be continued in the soil.

Maturation: It is the longest period. The mass in the degradation process becomes rich in humus, with a greater quantity of nutrients passing by the organic to mineral appearance, becoming usable by roots, with an increased content of colloidal material, which is responsible for improvement capacity of the soil. The material becomes well degraded and the original prime material can be hardly identified.

Before passing through these two stages, the compost is 'raw' and damages plants.

\section{COMPOSTING SYSTEMS}

As composting is a method that interacts with microorganisms, temperature, humidity and oxygenation, all necessary for ecological balance, should be controlled. Nowadays 
KALMAR ECO-TECH'03

Bioremediation and Leachate Treatment

KALMAR, SWEDEN, November 25-27, 2003

there are many technologies for producing organic compost, from housing composting (production around 10 to $50 \mathrm{~kg} /$ month) to industrial scale processes, used for greater volumes (more than $300 \mathrm{t} /$ month). When choosing a composting method many factors should be considered:

Volume of material to be processed. Large volumes of organic material require large areas for decomposition and maturation as windrows.

Equipment. Small volumes can be composted by hand, however, when the volume exceeds 30 tday, equipment such as shovels and excavators are necessary.

Material characteristic. Depending on the material, specific methodology should be chosen. For example: Low grain size material $(<30 \mathrm{~mm})$ composts more satisfactorily when oxygenation occurs around a revolving mass. When composting materials susceptible to contamination by heavy metals, masses should be static or oxygenated forcibly.

At the present time, the main composting methods used, in Brazil are the Natural Organic fraction of waste is left as windrows and the oxygenation, required by biological degradation, occurs with periodical revolving of the mass - and Accelerated - a series of operations that prepare the material to be digested and aims to achieve optimal aerobic fermentation during the digestion phase. In this method, waste is selected (by hand or mechanically).

The composting period should not be a fixed or imposed condition, albeit a result from biologic necessities, material characteristics, composting system and climatic conditions, among others. Both natural or accelerated processes require the same minimum period of time, from 60 to 90 days, left as windrows in open skies to complete the composting. Equipments for accelerating the process only work in the first phase of composting. (IPT / Cempre, 2000)

\subsection{The most used composting system in Brazil}

\subsubsection{Revolving windrow system}

After select the recyclables fraction, organic material are grinding and disposal as windrows, where biologic degradation begins (e.g. see Figure 1). These windrows are placed in open air and measure 1,50 to $1,80 \mathrm{~m}$ in height and 2,50 to $4,50 \mathrm{~m}$ in width. The revolving, handily or mechanically, provides an opportunity for repositioning of air and humidity and temperature controls, required for the process. The first phase of degradation varies from 60 to 90 days and the second phase, the maturation happens between the next 45 and 60 days. 
KALMAR ECO-TECH'03

Bioremediation and Leachate Treatment

KALMAR, SWEDEN, November 25-27, 2003

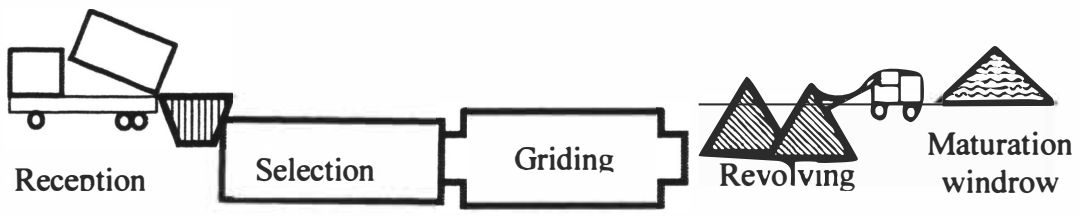

Figure 1. Basic flux gram of revolving windrow system's

\subsubsection{Statically and oxygenated forced windrows}

The basic difference between statically and oxygenated forced windrows system and revolving windrows system (e.g. see Figure 1) is the way that oxygenation occurs. In this case, oxygenation occurs by forced air insufflation. The air diffusion inside of the windrows is achieved by perforated tubes and an air blower.

Figure 2 shows composting silo where the air injection is made. In this case, the degradation is quicker than the system with revolving windrows. Digestion takes approximately 30 days and maturation varies between 45 to 60 days.

Both cases, forced air and natural aeration, windrows should be covered with humificated material, pieces of wood or inert residues in small pieces which serves as protection from bad weather, as well, as a filter against fetid gases.

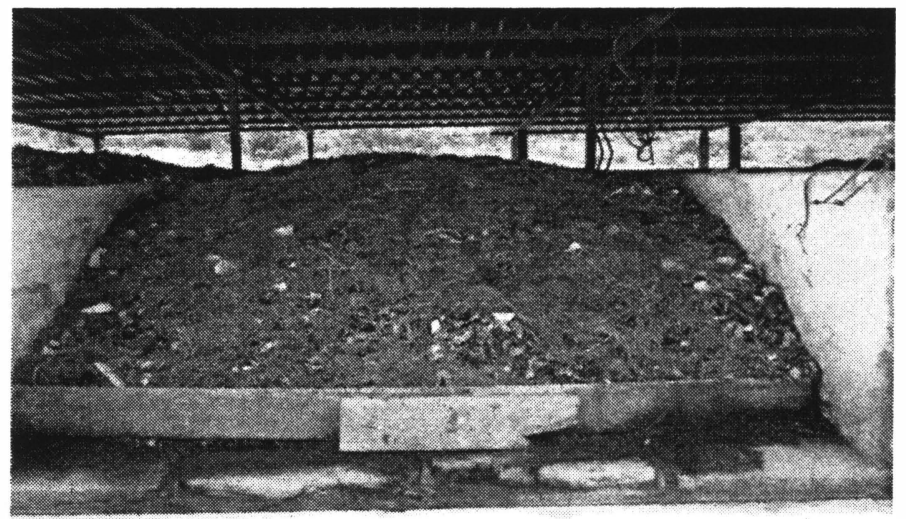

Figure 2. Silos of static and oxygenated forced windrow

\subsubsection{System with bio digester}

System with accelerated process with bio digester is a process improved by the Danishes, which allow a great reduction in the first phase of biologic degradation. This phase, when occurs inside a bio digester suffer a reduction arriving to 48 to 72 hours. The maturation period, however, takes the same 45 to 60 days used by the others systems. 
KALMAR ECO-TECH'03

Bioremediation and Leachate Treatment

KALMAR, SWEDEN, November 25-27, 2003

After an optional primary selection, the material enter the bio digester where is fermented (e.g. see Figure 3). The bio digester is a metallic rotative cylinder, which measures between $25 \mathrm{~m}$ and $30 \mathrm{~m}$ in length and $3,5 \mathrm{~m}$ of diameter (e.g. see Figure 4).

The cylinder rotates continually, triturating the waste by abrasion. The natural fermentation process heats the mass, due to the presence of microorganisms and the constant air insufflations, accelerating digestion and aerobic decomposition of the organic material. This reaction, caused by the high temperature, also destroys pathogenic organisms. After fermentation waste is sieved and inert pieces of material, are removed. At this stage, compost is left on a site of maturation, in the form of windrows during the maturation phase.

The advantage of this system is the short time required for the bio stabilization or digestion of the organic material and the possibility of expanding the system's capacity due to the fact that it is constructed in separated lines that can be enlarged without interruption. The disadvantages are related to costs for implantation and support. Contamination occurs mainly because there is no prioritising in the selection of inorganic

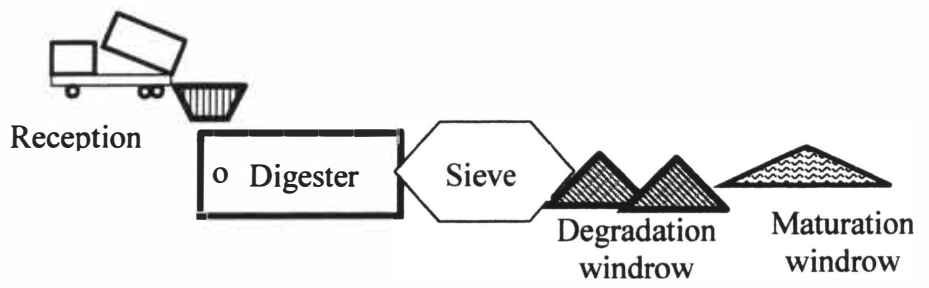

Figure 3. Basic flux gram of system with bio digester

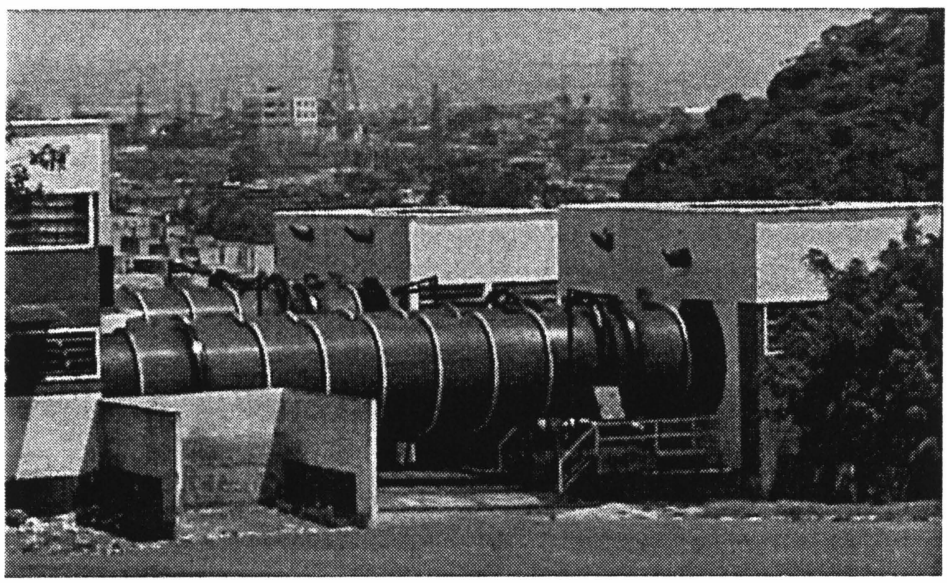

Figure 4. System with Bio digester -Dano- in São Paulo 
KALMAR ECO-TECH'03

Bioremediation and Leachate Treatment

KALMAR, SWEDEN, November 25-27, 2003

\section{COMPOST QUALITY}

\subsection{Fertility of Brazilian's compost.}

A large variation was found in the composition of compost, even when the comparison is made between different grain sizes of the same compost (e.g. see Table 2).

Table 2. Nutrients content present in the compost produced by Vitória's factory. (Baptista 2001)

\begin{tabular}{lccc}
\hline Compost item & $\begin{array}{c}\text { Grain Size } 30 \mathrm{~mm} \\
\text { results: } 4 \text { analyses } \\
\text { from } 07 / 92 \text { to } 05 / 94\end{array}$ & $\begin{array}{c}\text { Grain Size } 12 \mathrm{~mm} \\
\text { results: } 13 \text { analyses } \\
\text { from } 07 / 92 \text { to } 08 / 95\end{array}$ & $\begin{array}{c}\text { Grain Size 06mm } \\
\text { results:3 analyses } \\
\text { from } 05 / 94 \text { to } \\
02 / 96\end{array}$ \\
\hline Humiditye(\%) & 26 to 32 & 12 to 40 & - \\
Organic materiale(\%) & 21 to 34 & 19 to 38 & 21 to 29 \\
$\mathrm{C} / \mathrm{N}$ & $10.5 / 1$ to $17.1 / 1$ & $10.0 / 1$ to $16.2 / 1$ & $12.4 / 1$ to $15.5 / 1$ \\
$\mathrm{pH}$ & 7.1 toe8.1 & 6.5 to 8.0 & 7.6 \\
$\mathrm{~N}(\%)$ & 1.10 & 0.80 to 1.40 & 0.90 to 1.30 \\
$\mathrm{P}_{2} \mathrm{O}$ se(\%) & 0.39 to 0.60 & 0.30 to 0.82 & 0.64 to 0.80 \\
$\mathrm{~K} 2 \mathrm{Oe}(\%)$ & 0.49 to 0.66 & 0.34 to 1.08 & 1.01 to 1.08 \\
$\mathrm{CaOe}(\%)$ & 2.52 to 2.95 & 1,44 to 3,64 & 2.91 to 4.34 \\
$\mathrm{MgOe}(\%)$ & 0.23 to 0.35 & 0,15 to 0,42 & 0.27 to 0.38 \\
$\mathrm{Cu}(\mathrm{ppm})$ & 24 to 98 & 28 to 174 & 61 to 160 \\
$\mathrm{Zn}(\mathrm{ppm})$ & 83 to 300 & 76 to 385 & 127 to 374 \\
$\mathrm{Fe}(\mathrm{ppm})$ & 8405 to 14423 & 7813 to 21250 & 14331 toe30000 \\
$\mathrm{Mn}(\mathrm{ppm})$ & 158 to 216 & 90 to 250 & 250 to 312 \\
$\mathrm{~B}(\mathrm{ppm})$ & 01 to 09 & 01 to 19 & 02 to 19 \\
\hline
\end{tabular}

\subsection{Content of heavy metals in Brazilian's compost.}

The Table 3 shows that compost produced by different technologies, in different Brazilian cities, present very different heavy metal taxes. It can be observed that compost produced by a forced aeration system presents low heavy metal content, which points to the efficiency of static and oxygenated windrows when addressing the question of contamination. When revolving of the mass is not included, danger of contamination tends to decrease.

Critical analyses of heavy metal tax, however, should undertake careful evaluation of utilized methodologies to ensure effective comparison of results. Today, the majority of bibliography references make comparisons from totals and pseudo-totals extractions using high concentration and aggressiveness acids. This fact creates comparison parameters that are contested by many authors who consider it impossible to compare extractions made in laboratories, with mobilization of pollutants, to what happens under 


\section{KALMAR ECO-TECH'03}

Bioremediation and Leachate Treatment

KALMAR, SWEDEN, November 25-27, 2003

natural conditions. (Kiehl, 1998). Despite this, due to the absence of data comparisons that refer to other kinds of extractions, in conjunction with the deficiency of parameters for Brazilian compost, the presented works, generally, apply a methodology that uses comparison with foreign parameters made by total extraction.

Table 3. Heavy metals content of compost produced in Brazil ( $\mathrm{mg} / \mathrm{kg})$ (Cravo (1), Baptista, 2001 (3), Enterpa (2))

\begin{tabular}{llccccccc}
\hline FACTORY & SYSTEM & $\mathrm{Pb}$ & $\mathrm{Cu}$ & $\mathrm{Zn}$ & $\mathrm{Ni}$ & $\mathrm{Cr}$ & $\mathrm{Cd}$ & $\mathrm{Hg}$ \\
\hline São Paulo-SP (3) & Bio digester & 241 & 477 & 421 & 109 & 167 & 1.6 & 1.1 \\
Comlurb-RJ (3) & & 316 & 512 & 1115 & 386 & 542 & 3.4 & 3.0 \\
Comélio Procópio-PR & & 216 & 611 & 983 & 299 & 411 & 2.9 & 26.0 \\
(3) & & 293 & 324 & 270 & 22 & 81 & 0.6 & 0.57 \\
Vitória-ES 1991 (3) & Windrow & 105 & 115 & 256 & 10 & 45 & $>0.05$ & 0.36 \\
Vitória-ES 1993 (3) & Forced & oxygenation & & & & & \\
& & 238 & 177 & 279 & 25 & 94 & 2 & - \\
Belo Horizonte(1) & & 146 & 130 & 197 & 19 & 66 & 2.5 & - \\
Brasilia (1) & & 169 & 45 & 195 & 24 & 167, & 2 & - \\
Brasília (1) & selective process & & & & & 5 & & - \\
& & & & & & \\
Brasilia (2) & Bio digester & 348 & 222 & 522 & 12 & 25 & $<1$ & - \\
Rio de Janeiro (1) & & 599.3 & 815 & 1006 & 91 & 125 & 5 & - \\
Florianópolis (1) & & 92.3 & 46 & 111 & 11 & 29 & 1 & - \\
São Paulo (1) & Bio digester & 217.7 & 180 & 163 & 26 & 66 & 5 & - \\
Manaus (1) & & 209.3 & 208 & 430 & 27 & 81 & 2.2 & - \\
\hline
\end{tabular}

Table 4. Tolerance limits for heavy metals in compost made of urban solid waste (mg/kg) (Mahler 2002)

\begin{tabular}{lccccccc}
\hline $\begin{array}{l}\text { Countries/ } \\
\text { Organisms }\end{array}$ & $\mathrm{Pb}$ & $\mathrm{Cu}$ & $\mathrm{Zn}$ & $\mathrm{Ni}$ & $\mathrm{Cr}$ & $\mathrm{Cd}$ & $\mathrm{Hg}$ \\
\hline Germany & 150 & 100 & 400 & 50 & 100 & 1.5 & 1 \\
Suisse & 150 & 150 & 500 & 50 & 150 & 3 & 3 \\
France & 1600 & 2000 & 6000 & 400 & 2000 & 40 & 20 \\
Austria & 200 to 900 & 0 to 1000 & 300 to 1500 & 30 to 200 & 50 to 300 & 1 to 6 & 1 to 4 \\
Holland & 500 & 600 & 2000 & 100 & 500 & 5 & 5 \\
Belgium & 600 & 100 & 1000 & 50 & 150 & 5 & 5 \\
EPA & 300 & 1500 & 2800 & 420 & 1200 & 39 & 17 \\
CCE & 1000 to & 1000 to 1750 & 2500 do & 300 to 400 & -- & 20 to 40 & 16 to \\
\hline
\end{tabular}

As there are no parameters of reference for maximum content of heavy metal for compost made by solid waste in Brazil, it is usual to compare to values from other countries. However, the variability between the range of those values in different countries or organization is great, as may be observed in Table 4 . 
KALMAR ECO-TECH'03

Bioremediation and Leachate Treatment

KALMAR, SWEDEN, November 25-27, 2003

\section{IMPLEMENTATION OF COMPOSTING FACTORIES IN BRAZIL}

A report made by Lua (1999) presented that State of Rio de Janeiro invested, during 20 years, US\$ 50 millions for constructing 15 factories of composting and selection of recyclable materials from urban solid waste. 11 of these factories were closed or had its construction stopped before finished. Just 4 of them are still working, however, only 2 are doing it properly (e.g. see Table 5).

The responsibles for these disasters give many reasons for it, but they may be resumed in no planning in different sectors (management, political, technical). The elevated operational costs and the low quality of the product are pointed as responsible by the fail of the factories. However, they are being built without a pre analysis of the system and design. Many districts buy an already done composting system, without a previous study and without knowing anything about its waste characteristics (volume per day, organic matter content, recyclable fraction content, and others). Besides, cities accepted factories without notion of its cost for maintenance. Add to this, some factories was begin to be built or was inaugurated just before government elections and construction was abandoned after it.

Table 5: List of composting factories built in Rio de Janeiro state, time that they operated (year) and price paid by government (US\$). (Lua, 1999)

\begin{tabular}{|c|c|c|c|}
\hline Factory & Time of operation & Price US\$ & Observation \\
\hline Cajú & 2 years & 23 millions & Strong smell, unadequated system \\
\hline Jacarepaguá & 5 years & & Strong smell \\
\hline Irajá & 26 years & 1.5 million & $\begin{array}{l}\text { Height operational costs and low } \\
\text { quality of the product. It works as } \\
\text { place for selecting recyclable } \\
\text { material. }\end{array}$ \\
\hline Nova Iguaçú & never & 2.5 millions & \\
\hline Magé & never & 1.5 million & Closed by judicial seizure \\
\hline Cantagalo & since march 1999 & 180 thousand & $\begin{array}{l}\text { Operates } 95 \% \text { of the collected waste } \\
\text { which processes } 50 \text { ton/day }\end{array}$ \\
\hline Paraíba do Sul & since may 1998 & 150 thousand & Operates with $33 \%$ of total capacity \\
\hline Petrópolis & 30 years & 500 thousand & \\
\hline Niterói & never & 1.5 million & Obsolete design \\
\hline São Gonçalo & never & 1.5 million & \\
\hline Bom Jardim & since 1998 & 50 thousand & Operates with $48 \%$ of total capacity \\
\hline Belford Roxo & never & 2.5 millions & Administrative issues \\
\hline Friburgo & Since 1992 & 300 thousand & \\
\hline Saquarema & 5 years & 40 thousand & Closed by judicial seizure \\
\hline Queimados & never & 2.5 millions & \\
\hline
\end{tabular}




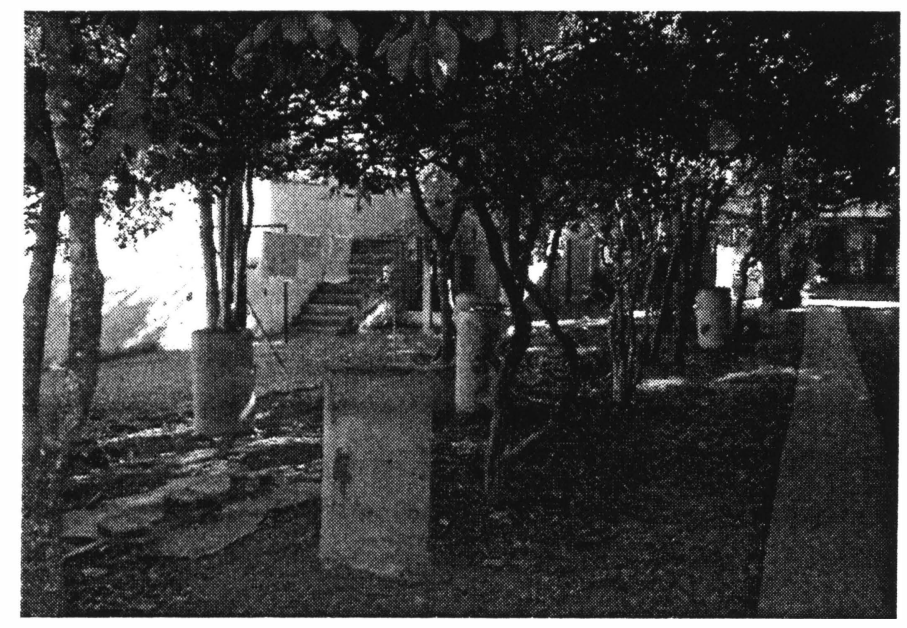

Figure 5. Composting system using concrete tubes at a house's yard

There are few successful cases, however. The factories of Cantagalo and Friburgo (e.g. see Table 5), work properly since they were built. Both cases, cities are situated in an agricultural area of the state. They have a well administrate waste collection system and the composting factories were constructed by local district and are operate by private organizations. Cantagalo collect 15 ton/day of waste. The compost is well accepted by community and there are even demand for more. Friburgo collect 151 ton/day of waste.

An example of an individual and successful composting in a domestic scale occurs in São Paulo, where a simple technique has been used since the beginning of 1990. In this case, ten concrete tubes were laid out in the yard (e.g. see Figure 5). Household organic waste is mixed with ground leaves and pieces of wood severed from trees. The mixture is placed inside the first concrete tube, and a decomposition accelerator, which is a mass inoculated with microorganism, is added. Weekly, this mixture is transferred to the next concrete tube, being revolved and oxygenated during this process. At the end of ten weeks, when the mixture has lain in all of the ten tubes for one week, the compost is ready to be used as an organic fertilizer.

\section{CONCLUSIONS}

From the material studied it can be observed that Brazil has an enormous potential for composting when considering the high quantity of organic material produced; the good climatic conditions, the availability of space for compost windrows to remain where they are after they reach the maturation phase and the high availability of local work force to take care of the windrows. However, new technologies, more adequate for our reality should be studied and developed especially in small towns where the majority of the 
KALMAR ECO-TECH'03

Bioremediation and Leachate Treatment

KALMAR, SWEDEN, November 25-27, 2003

houses have yards that allow composting, but also in big cities, where the materials from food supply centres are basically composed of organic material.

In spite of the adequate characterises of Brazilian urban waste for composting, after several experiences the process are not implemented in a way that it could be considered an advantageous procedure for less industrialised countries. Many experiences with composting factories are giving no results and are abandoned after some tries.

Management problems, discontinuation in municipal political administration, difficulties in the privatisation of the waste collection system, no administrative power from public organism in environmental control and irresponsibility of public managers with public money are some of the reasons that work against development of composting in an industrial way in Brazil.

\section{ACKNOWLEDGEMENTS}

The authors thank the National Research Council (CNPq) for its constant support. Both authors thank Enterpa Ambiental S.A for data.

\section{REFERENCES}

[1] Baptista F.R.M. (2001). Phisical and comercial charactherization of domestic waste of Vitória - ES by function of social class of population. 260 p. Thesis, Programme of Post-graduation in Environmental Engenearing, Federal University of Espírito Santo, Vitória. (in Portuguese).

[2] Cravo, M S, Muraoka T, Giné M.F., S, (1998), Chemical characterization of compost made by urban solid waste of some Brazilian's factories. Brazilian magazine of soil science, 22, May pp 547-553 (in Portuguese).

[3] IPT/Cempre (2000). Municipal waste: manual of integrated management. $2^{\text {nd }}$ ed. São Paulo: IPT. 370 p. (in Portuguese).

[4] Kiehl, E.J.(1998). Composting manual: Maturation and compost quality. Ed.: Edmar José Kiehl. São Paulo. 171 p. (in Portuguese).

[5] Lua, D.(1999) - The 50 millions dollars put out in the waste, Journal of Brazil Newspaper, 12 dezember 1999. p.81 (in Portuguese)

[6] Mahler C, Schueler A. (2002) 'Compostagem'. In Polution: acquatic and solid waste polution, Mahler C, Araújo F \& Paranhos R (Erds.). Aquarius Rio de Janeiro, pp. 95117. (in Portuguese)

[7] Tchobanoglous G., Theisen H., Vigil S. A., (1994) Integral management of solid waste. McGraw-Hill, Madrid:, Inc. v(s). 1-2, 6 p. 